\title{
Assessment of Particulate Matter-Based Air Quality Index in Port Harcourt, Nigeria
}

\author{
Oladapo M Akinfolarin ${ }^{*}$, Ndokiari Boisa and Charles C Obunwo
}

Department of Chemistry, Rivers State University, Port Harcourt, PMB 5080, Nkpolu-Oroworukwo, Nigeria

*Corresponding author: Oladapo M Akinfolarin, Department of Chemistry, Rivers State University, Port Harcourt, PMB 5080, Nkpolu-Oroworukwo, Nigeria, Tel: +2348064214910; E-mail: oladapo.akinfolarin@ust.edu.ng

Received date: November 23, 2017; Accepted date: November 27, 2017; Published date: December 04, 2017

Copyright: @ 2017 Akinfolarin OM, et al. This is an open-access article distributed under the terms of the Creative Commons Attribution License, which permits unrestricted use, distribution, and reproduction in any medium, provided the original author and source are credited.

\begin{abstract}
Due to the desire of nations to enhance their economic status, industrialization is vigorously pursued. Industrialization is historically associated with environmental degradation. In developing countries, due to lack of environmental awareness, the level of industrialization is not commensurate with environmental studies and monitoring. This study was designed to assess the status of particulate matter at three emerging industrial sites in Port Harcourt. To achieve this, Aerocet 531 monitor was used. To be able to communicate properly with the general public, data obtained were expressed in terms of Air Quality Index (AQI). The results showed that industrial sites had higher concentrations compared to the control for both $\mathrm{PM}_{2.5}$ and $\mathrm{PM}_{10}$. Seasonal variation of $\mathrm{PM}_{2.5}$ and $\mathrm{PM}_{10}$ were observed with the dry season indicating concentrations higher than the local acceptable limits of $150 \mu \mathrm{g} / \mathrm{m}^{3} \mathrm{and} 230$ $\mu \mathrm{g} / \mathrm{m}^{3}$. The AQI of the three emerging industrial sites indicated a category for 'good' to 'moderate' for wet season while for dry season, they varied from 'very unhealthy' to 'hazardous' in all the sampling areas. This poses a great threat to health and environment of the inhabitants.
\end{abstract}

Keywords: Air quality index; Index values; Air pollutants; Industrial areas; Port Harcourt

\section{Introduction}

One of the basic necessities and requirements of human existence is clean air [1,2]. Contamination of air arises from anthropogenic activities and natural events (e.g., volcano) which has been on increase due to industrialization and human quest for development. These activities release some gaseous emissions $\left(\mathrm{SO}_{2}, \mathrm{NO}_{2}, \mathrm{CO}, \mathrm{H}_{2} \mathrm{~S}\right.$, VOCs and hydrocarbons) and particulates (smoke, soot, metallic, dust, fumes and aerosols) that contaminate air, and when in high concentrations could cause damage to environment and human health [3]. Industrial activities that contaminate air are distributed globally [4,5]. In Port Harcourt, one of the cities in Nigeria, only few studies have been conducted on the quality of air [6-9]. The few previous studies however presented air data and compared same with standard limits. Their data did not convey information on the air quality status to the public in an explicit manner. AQI has been developed to integrate air quality characteristics worldwide [10-13].

AQI is used for reporting daily air quality of how clean or polluted the air is and its associated health effects of concern [14]. It is obtained by evaluating measured pollutant concentrations into index values. Air Index value is the pollutant concentration expressed as a proportion of the threshold value. It makes it easier to interpret air quality data because it reduces the complexity associated with pollutant concentration. Index value over 100 suggests the pollutant concentration exceeds the air quality standard, and is considered to be unhealthy at first for certain sensitive groups of people, then for everyone as AQI values get higher. The AQI has always been used for five air pollutants: $\mathrm{CO}, \mathrm{SO}_{2}, \mathrm{NO}_{2}, \mathrm{PM}_{2.5}$ and $\mathrm{PM}_{10}$. The aim of this study is to assess air quality index of emerging industrial sites in Port Harcourt.

\section{Study area}

Port Harcourt (latitudes $4^{\circ} 49 / \mathrm{N}$, longitudes $7^{\circ} 2 / \mathrm{E}$ ), the capital city of Rivers State, the hub of oil and gas industry in Nigeria is situated along the Bonny River. Its metropolis stretches from International airport at Omagwa and also from the Refinery at Eleme to Choba Community. The entire metropolis is an area between 1300 and 1800 $\mathrm{km}^{2}$ with an active population of over six million people [15].

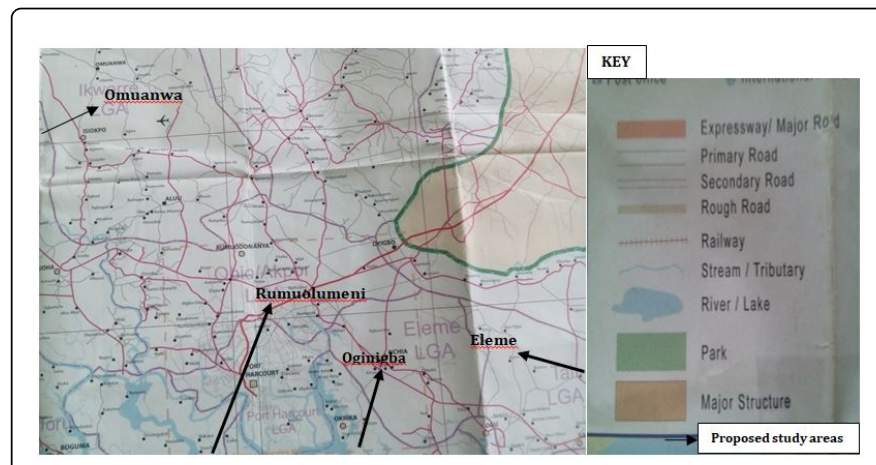

Figure 1: Map of the study area showing sampling locations.

The city has a tropical wet climate with long and heavy rainy season and very short dry season. The average monthly rainfall ranges between 20.7 and $434.0 \mathrm{~mm}$, with an annual level of more than 3000 $\mathrm{mm}[15,16]$. November to January is its lowest rainfall period while February to June is its first peak, followed by the second peak in September [16]. The temperature has little variation average between $25-28^{\circ} \mathrm{C}[15,16]$. Three emerging industrial areas were selected namely Rumuolumeni $(\mathrm{Rm})$, Oginigba $(\mathrm{Og})$ and Eleme $(\mathrm{El})$, and one nonindustrial site at Omuanwa $(\mathrm{Om})$, as control for sampling locations (Figure 1). Activities around these areas included commercial, 
Page 2 of 4

construction works, cement-block molding industries, building infrastructures, dredging of white sand, and farming, alongside other non-point industrial activities.

\section{Materials and Methods}

Sampling: Twelve points were sampled for $\mathrm{PM}_{10}, \mathrm{PM}_{2.5}, 3$ points each from industrial areas and 3 points from the control. Potential air contaminants commonly used in AQI were measured in the study areas. The equipment used was potable digital hand held air monitors. These monitors include Aerocet 531 monitor for $\mathrm{PM}_{10}$ and $\mathrm{PM}_{2.5}$ and Automated GPS for sampling points coordinates. All equipment was pre-calibrated before usage for quality assurance purposes. The air quality sampling was conducted in 2016 for wet and dry seasons.

\section{Data analysis and interpretation}

Mean levels of each air parameter were calculated using excel spreadsheet. The AQI was calculated for all the sampling areas using the daily average concentration of the measured parameters. The AQI is divided into six groups with a specific colour assigned to each in order to comprehend at first glance whether air contaminants are approaching unhealthy levels in the area (Table 1).

\begin{tabular}{|l|l|l|}
\hline AQI & Levels of health concern & Colours \\
\hline $0-50$ & Good & Green \\
\hline $51-100$ & Moderate & Yellow \\
\hline $101-150$ & Unhealthy for sensitive groups & Orange \\
\hline $151-200$ & Unhealthy & Red \\
\hline $201-300$ & Very unhealthy & Purple \\
\hline $301-500$ & Hazardous & Maroon \\
\hline
\end{tabular}

Table 1: Air Quality Index (AQI) values, health concerns and color codes. *Source: https://www.airnow.gov

The AQI was computed by a linear function by interpolating the concentration of the pollutant in the equation below:

$$
\mathrm{Ip}=\mathrm{I}_{\mathrm{Hi}}-\mathrm{I}_{\mathrm{Lo}} / \mathrm{BP}_{\mathrm{Hi}}-\mathrm{BP}_{\mathrm{Lo}}\left(\mathrm{C}_{\mathrm{p}}-\mathrm{BP}_{\mathrm{Lo}}\right)+\mathrm{I}_{\mathrm{Lo}}
$$

*Source: https://stimulatedemissions.wordpress.com

Where $\mathrm{I}_{\mathrm{Lo}}=$ the AQI of pollutant ' $\mathrm{p}$ '; $\mathrm{C}_{\mathrm{p}}=$ the actual ambient concentration of the pollutant ' $\mathrm{p}$ '; $\mathrm{BP}_{\mathrm{Hi}}=$ the breakpoint that is $\geq \mathrm{C}_{\mathrm{p}}$ (upper limit); $\mathrm{BP}_{\mathrm{Lo}}=$ the breakpoint that is $\leq \mathrm{C}_{\mathrm{p}}$ (lower limit); $\mathrm{I}_{\mathrm{Hi}}=$ the AQI value corresponding to $\mathrm{BP}_{\mathrm{Hi}}$ and $\mathrm{I}_{\mathrm{Lo}}=$ the $\mathrm{AQI}$ value corresponding to $\mathrm{BP}_{\mathrm{Lo}}$.

\section{Results and Discussion}

Details of GPS coordinates for $\mathrm{Rm}, \mathrm{Og}, \mathrm{El}$ and $\mathrm{Om}$ and their corresponding concentrations of particulate matter $\left(\mathrm{PM}_{2.5}\right)$ for both wet and dry season are provided in Table 2.

Results for particulate matter $\left(\mathrm{PM}_{10}\right)$ for the four sampled locations and their geo-locations are listed in Table 3.

Outputs from AQI model for wet and dry seasons are listed in Tables 4 and 5 respectively.

\section{$\mathrm{PM}_{2.5} \mu \mathrm{m}$}

Concentrations of the $<2.5 \mu \mathrm{m}$ particulate matter for the wet season ranged from $8.90-22.40 \mu \mathrm{g} / \mathrm{m}^{3}, 18.70-34.75 \mu \mathrm{g} / \mathrm{m}^{3}, 11.05-31.35 \mu \mathrm{g} / \mathrm{m}^{3}$ and $2.90-7.85 \mu \mathrm{g} / \mathrm{m}^{3}$ for Rumuolumeni, Oginigba, Eleme and Omuanwa, respectively (Table 2). Concentrations of $<2.5 \mu \mathrm{m}$ particulate matter for dry season ranged from $181.35-245.65 \mu \mathrm{g} / \mathrm{m}^{3}$, $148.85-300.35 \mu \mathrm{g} / \mathrm{m}^{3}, 149.90-182.30 \mu \mathrm{g} / \mathrm{m}^{3}$ and $143.80-156.75 \mu \mathrm{g} / \mathrm{m}^{3}$ for Rumuolumeni, Oginigba, Eleme and Omuanwa, respectively (Table 2). The $<2.5 \mu \mathrm{m}$ particulate matter concentrations observed in this study for dry season were about ten times higher than those reported by Gupta [17] following satellite remote sensing of cities in India, Australia, Hong Kong, Switzerland and USA. However, the values, $16.25 \pm 6.91 \mu \mathrm{g} / \mathrm{m}^{3}, 26.17 \pm 8.08 \mu \mathrm{g} / \mathrm{m}^{3}, 22.75 \pm 10.50 \mu \mathrm{g} / \mathrm{m}^{3}$ and 5.52 $\pm 2.49 \mu \mathrm{g} / \mathrm{m}^{3}$ observed for the four stations in this study are very similar to $16.2 \pm 7.50 \mu \mathrm{g} / \mathrm{m}^{3}, 22.5 \pm 13.50 \mu \mathrm{g} / \mathrm{m}^{3}, 15.20 \pm 12.00 \mu \mathrm{g} / \mathrm{m}^{3}$ reported by Gupta for Richmond, Australia, Lugano, Switzerland and New York, USA, respectively [17].

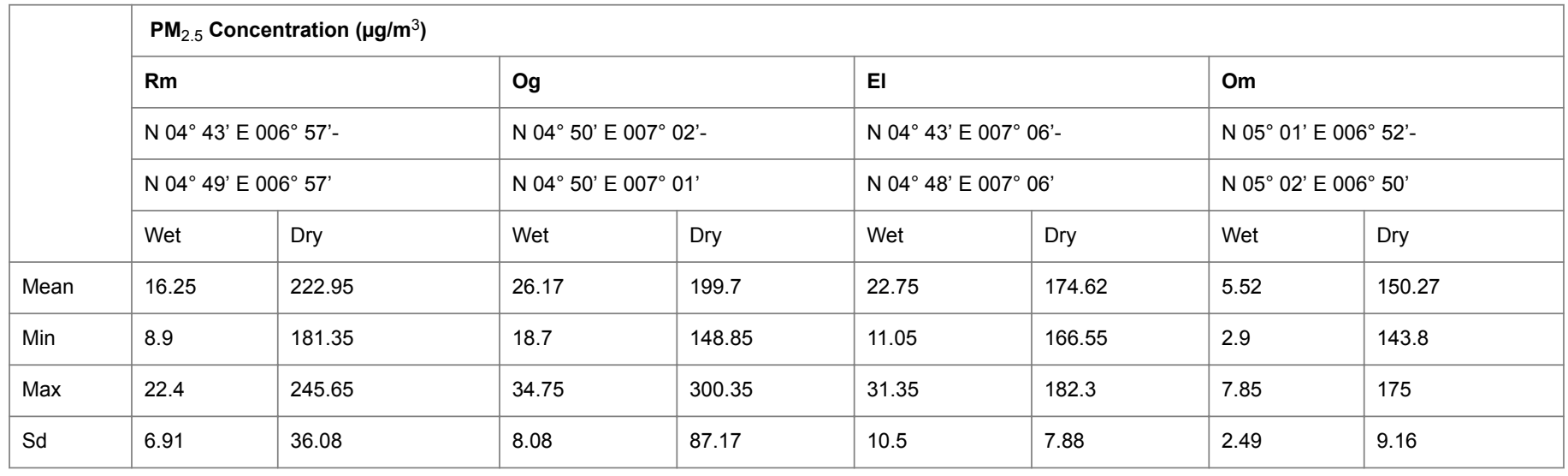

Table 2: Mean, minimum, maximum and standard deviations of $\left(\mathrm{PM}_{2.5}\right)$ for both dry and wet seasons, where, Rm=Rumuolumeni; Og=Oginigba; $\mathrm{El}=$ Eleme; $\mathrm{Om}=$ Omuanwa. 
Page 3 of 4

\section{$\mathrm{PM}_{10} \mu \mathrm{m}$}

Concentrations of the $<10 \mu \mathrm{m}$ particulate matter for wet season ranged from $30.85-82.75 \mu \mathrm{g} / \mathrm{m}^{3}, 42.80-65.50 \mu \mathrm{g} / \mathrm{m}^{3}, 22.60-135.50$ $\mu \mathrm{g} / \mathrm{m}^{3}$ and $5.65-15.45 \mu \mathrm{g} / \mathrm{m}^{3}$ for Rumuolumeni, Oginigba, Eleme and Omuanwa, respectively (Table 3). Concentrations for dry season ranged from 236.00-1926.30 $\mu \mathrm{g} / \mathrm{m}^{3}, \quad 940.25-1399.80 \mu \mathrm{g} / \mathrm{m}^{3}$, $960.20-1154.45 \mu \mathrm{g} / \mathrm{m}^{3}$ and $177.85-855.60 \mu \mathrm{g} / \mathrm{m}^{3}$ for Rumuolumeni, Oginigba, Eleme and Omuanwa, respectively (Table 3 ). The observed values in this study showed that the concentrations in the dry season were more than thirteen times those of the wet season. However, the mean values of $54.17 \mu \mathrm{g} / \mathrm{m}^{3}, 50.40 \mu \mathrm{g} / \mathrm{m}^{3}$ and $78.78 \mu \mathrm{g} / \mathrm{m}^{3}$ for Rumuolumeni, Oginigba and Eleme respectively were higher than those reported by Jonathan [18] for Phoenix, in Arizona, Santa AnaAnaheim, in California and in Los Angeles, with mean concentrations of $39.70 \mu \mathrm{g} / \mathrm{m}^{3}, 37.40 \mu \mathrm{g} / \mathrm{m}^{3}$ and $46.00 \mu \mathrm{g} / \mathrm{m}^{3}$ respectively.

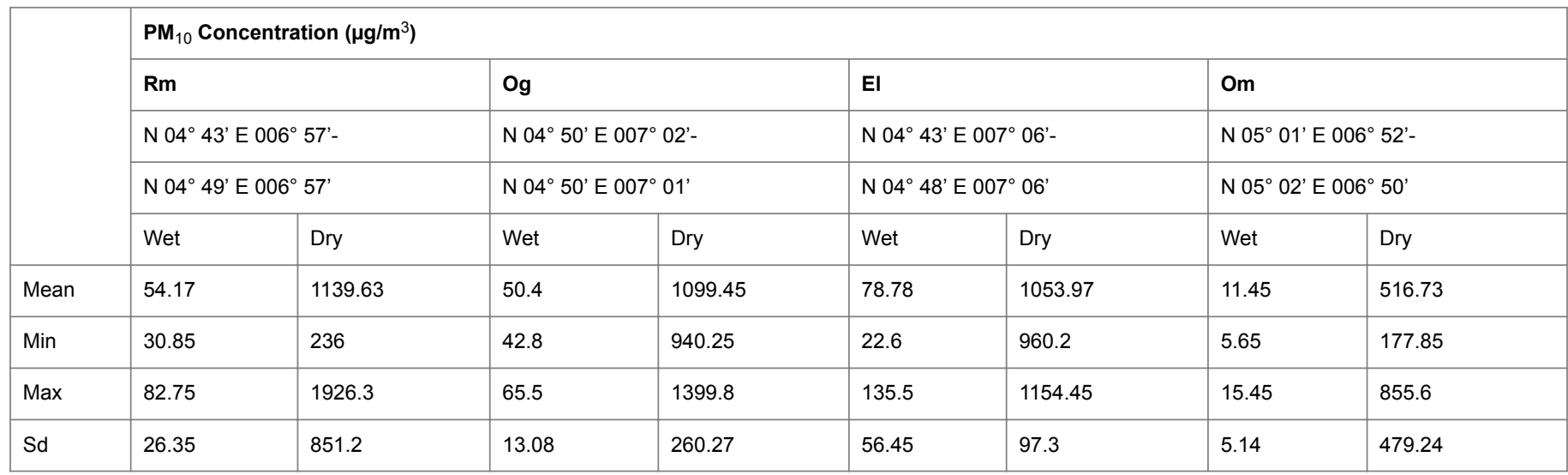

Table 3: Mean, minimum, maximum and standard deviations of $\left(\mathrm{PM}_{10}\right)$ for both dry and wet season.

\section{Seasonal variation}

Higher concentrations of $\mathrm{PM}_{2.5}$ and $\mathrm{PM}_{10}$ were observed in the dry than in wet season. This agrees with the studies carried out by Ede and Gobo [7,9]. The higher concentrations reported could be attributed a scavenging effect of the atmosphere and dissolving gaseous pollutants during the wet season $[19,20]$. Where there is high rainfall, air quality is generally better. The mean levels of particulate matters $\left(\mathrm{PM}_{10}\right)$ for dry season, in all the sampling areas were higher than the DPR limits of 150 and $230 \mu \mathrm{g} / \mathrm{m}^{3}$; while within for $\mathrm{PM}_{2.5}$. There was significant difference between the wet and dry season $(\mathrm{p}<0.05)$. The particulate matters in all the sampling locations were higher in the industrial areas than Omuanwa, the control, being the non-industrial site. Studies have shown that suspended particulate matter in industrial zones are higher due to wind-blown dust from roads, emissions from machineries in the industry and industrial vehicles [21,22]. Comparatively, the means levels of $\mathrm{PM}_{10}$ obtained in wet and dry seasons followed the trend $\mathrm{Rm}>\mathrm{Og}>\mathrm{El}>\mathrm{Om}$.

Particulate matter may cause damage by discoloring or destroying painted surfaces, corrode metals and building surfaces, soil, textiles and clothing. It may lead to climate change such as net cooling for refractive particles while some (soot) absorb energy and lead to warming and other change in timing and location of traditional rainfall pattern. Particulate sources include electric power plants, industrial facilities, automobiles, biomass burning and fossil fuels used in homes and factories for heating.

\section{Air Quality Index (AQI) of the pollutants}

The AQI of the pollutants were obtained in order to evaluate the health risks which the public are exposed to due to air pollution. The results of AQI data for the four locations are presented in Tables 4 and 5 for wet and dry seasons respectively. The health message for wet season ranged from good in Om to moderate in all the industrial areas with maximum being 80 and 23 as minimum, the AQI for the day was $\mathrm{PM}_{2.5}$. Table 5 indicates the AQI for the day to be $\mathrm{PM}_{10}$ with health message varied from very unhealthy in $\mathrm{PM}_{2.5}$ to hazardous in $\mathrm{PM}_{10}$ in all the study areas.

Nwaogazie and Zagha [23] reported that the AQI of all study areas in Port Harcourt, in exception of Bodostreet or new GRA, posed serious health risks to individuals who spent long hours and those sensitive groups such as asthmatics, children and elderly, people with heart or lung diseases were at highest risk [23]. Airborne particulate matter has negative effect to health [24] and has previously been estimated to cause between 3 and 7 million deaths every year, primarily by creating or worsening cardio-respiratory disease [25].

\begin{tabular}{|l|l|l|l|l|l|l|}
\hline & $\mathbf{P M}_{2.5}$ & PM $_{10}$ & $\begin{array}{l}\text { AQI for } \\
\text { the day }\end{array}$ & $\begin{array}{l}\text { Pollutant } \\
\text { characterize the AQI }\end{array}$ & $\begin{array}{l}\text { Colour } \\
\text { code }\end{array}$ & Category \\
\hline $\mathrm{Rm}$ & 60 & 50 & 60 & PM2.5 & Yellow & Moderate \\
\hline $\mathrm{Og}$ & 80 & 46 & 80 & PM2.5 & Yellow & Moderate \\
\hline $\mathrm{EI}$ & 73 & 62 & 73 & PM2.5 & Yellow & Moderate \\
\hline Om & 23 & 10 & 23 & PM2.5 & Green & Good \\
\hline
\end{tabular}

Table 4: Air Quality Index (AQI) for wet season.

\begin{tabular}{|l|l|l|l|l|l|l|}
\hline & $\mathbf{P M}_{2.5}$ & $\mathbf{P M}_{10}$ & $\begin{array}{l}\text { AQ for } \\
\text { the day }\end{array}$ & $\begin{array}{l}\text { Pollutant that } \\
\text { characterize the AQI }\end{array}$ & $\begin{array}{l}\text { Colour } \\
\text { code }\end{array}$ & Category \\
\hline $\mathrm{Rm}$ & 273 & $>500$ & $>500$ & PM10 & Maroon & Hazardous \\
\hline $\mathrm{Og}$ & 250 & $>500$ & $>500$ & PM10 & Maroon & Hazardous \\
\hline $\mathrm{EI}$ & 225 & $>500$ & $>500$ & PM10 & Maroon & Hazardous \\
\hline Om & 225 & $>500$ & $>500$ & PM10 & Maroon & Hazardous \\
\hline
\end{tabular}

Table 5: Air Quality Index (AQI) for dry season. 


\section{Conclusion}

Results of our assessment of atmospheric particulate matter at the three emerging industrial sites indicated higher concentrations compared to our control for both $\mathrm{PM}_{2.5}$ and $\mathrm{PM}_{10}$. $\mathrm{PM}_{2.5}$ and $\mathrm{PM}_{10}$ data from this study indicated seasonal variation with the dry season indicating concentrations higher than local acceptable limits of 150 $\mu \mathrm{g} / \mathrm{m}^{3}$ and $230 \mu \mathrm{g} / \mathrm{m}^{3}$. The AQI of the three emerging industrial sites indicated a category for 'good' to 'moderate' for wet season while for dry season, they varied from 'very unhealthy' to 'hazardous' in all the sampling areas. The activities of some of the industries located at these emerging industrial sites may be contributing particulate matter of human health relevant sizes into the atmosphere. People with respiratory disease, such as asthma, may be affected if they are exposed to particulate matter at the emerging industrial sites. There should be regular monitoring of air quality at new industrial sites like the ones investigated in this study.

\section{Acknowledgement}

We wish to extend our regards to Mr. Eze and Mr. Prince Azubuike, who were part of the team work.

\section{References}

1. Hassan SM, Abdullahi ME (2012) Evaluation of Pollutants in Ambient Air: A Case Study of Abuja, Nigeria. International Journal of Science and Research 2: 1-5.

2. Mohammed Y, Caleb JJ (2014) Assessment of some air pollutants and their corresponding air quality at selected activity areas in Kaduna metropolis. Proceeding of 37th Annual international conference of Chemical society of Nigeria (SCN) at Uyo, AkwaIbom State, Nigeria. 7th-12th September 1: 38-44.

3. Rai R, Rajput M, Agrawal SB (2011) Gaseous air pollutants: Review of a current and future trends of emissions and impacts on agriculture. Journal of Scientific Research 55: 77-102.

4. Al-Salem SM, Bouhamrah WS (2006) Ambient Concentrations of Benzene and other VOCs at Typical Industrial Sites in Kuwait and their Cancer Risk Assessment. Research Journal of Chemistry and Environment 10: 42-46.

5. Abu-Allaban M, Abu-Qudais H (2011) Impact Assessment of Ambient Air Quality by Cement Industry: A Case Study in Jordan. Aerosol and Air Quality Research 11: 802-810.

6. Njoku KL, Rumide TJ, Akinola MO, Adesuyi AA, Jolaoso AO (2016) Ambient Air Quality Monitoring in Metropolitan City of Lagos, Nigeria. Journal of Applied Science and Environmental Management (JASEM) 20: 178-185.

7. Gobo AE, Ideriah TJK, Francis TE, Stanley HO (2012) Assessment of Air Quality and Noise Around Okrika Communities, Rivers State, Nigeria. J Appl Sci Environ Manage 16: 75-83.

8. Nwokocha CO, Edebeatu CC, Okujagu CU (2015) Measurement, Survey \& Assessment of Air Quality in Port Harcourt, South-South Nigeria. International Journal of Advanced Research in Physical Science (IJARPS) 2: 19-25.

9. Ede PN, Obunwo CC, Nleremchi SC (2010) Air Quality Studies Around Some Local Palm Oil Mill Plants at the Northern Fringes of the Niger Delta Area, Nigeria. J Chem Soc 35: 6-10.

10. UK (1998) Air pollution. What it means for your health. Department of the Environment, Transport and the Regions, Wetherby L523 7NB, UK.

11. Malaysia (1997) A guide to air pollutant index in Malaysia, Kuala Lumpur. Department of Environment.

12. Ontario (1991) A guide to the Ontario Air Quality Index System. Ontario Ministry of the Environment, Torornto, Ont. Canada ISBN 0-7729-8230-9. Air Resource Branch.
13. GVAQI (1917) Greater Vancouver Regional District, Air Quality and Source control Department of Burnaby, BC Canada.

14. EPA (2014) Air Quality Index (AQI). A guide to air quality and your health. US Environmental Protection Agency Office of Air Quality Planning and Standards Outreach and Information Division Research Triangle Park, North Carolina. EPA-456/F-14-002, pp. 1-12.

15. Average monthly weather in Port Harcourt. Accessed September 25, 2017.

16. Weather and Climate in Port Harcourt, Nigeria. Accessed September 25, 2017.

17. Gupta P, Christopher AS, Wang J, Gehring R, Lee YC, et al. (2006) Satellite remote sensing of particulate matter and air quality assessment over global cities. Atmospheric Environment 40: 5880-5892.

18. Jonathan M, Samet MD, Francesca D, Frank C, Curriero WC, et al. (2000) Fine Particulate Air Pollution and Mortality in 20 U.S Cities 1987-1994. The New England Journal of Medicine 343: 1742-1749.

19. Bhatia SC (2002) Environmental Chemistry, India, CBS Publishers, New Delhi-110002, pp. 132-161.

20. NADP (1982) National Annual Data Summary of Precipitation Chemistry in the United States, pp. 1-20.

21. Akuro A (2012) Air quality survey of some locations in the Niger Delta Area. Journal of Applied Science and Environmental Management 16: 137-146.

22. Ukpebor EE, Okolo PO (2002) Measurement of NO2 \& O3, Ambient concentrations in a Project area in Niger Delta Region of Nigeria. Nigerian Journal of Chemical Research 7: 2002-2004.

23. Nwaogazie IL, Zagha O (2015) Roadside Air pollution assessment in Port Harcourt, Nigeria. Standard Scientific Research and Essays 3: 066-074.

24. Beelen R, Raaschou-Nielsen O, Stafoggia M, Andersen ZJ, Weinmayr G (2013) Effects of long-term exposure to air pollution on natural-cause mortality: An analysis of 22 European cohorts within the multicentre ESCAPE project. Lancet 383: 785-795.

25. Hoek G, Krishnan RM, Beelen R, Peters A, Ostro B, et al. (2013) Longterm air pollution exposure and cardiorespiratory mortality: A review. Environmental Health 12: 43-45. 